\title{
Prophylactic Caesarean Iliac Artery Balloon Insertion in Patients with Abnormal Placental Implantation
}

\author{
CSC Tsai ${ }^{1}$, SSM Wong ${ }^{1}$, CMY Chung ${ }^{2}$, SCH Yu ${ }^{1}$ \\ ${ }^{I}$ Department of Imaging and Interventional Radiology, Prince of Wales Hospital, Hong Kong \\ ${ }^{2}$ Department of Obstetrics and Gynaecology, Prince of Wales Hospital, Hong Kong
}

\begin{abstract}
Introduction: We evaluated the safety and obstetric outcomes of patients with abnormal placental implantation who underwent prophylactic Caesarean iliac balloon insertion.

Methods: Clinical and procedural records of patients with abnormal placental implantation (i.e., high-grade placenta praevia and/or placenta accreta) undergoing prophylactic Caesarean iliac artery balloon insertion in a tertiary referral hospital from September 2009 to April 2016 were reviewed. Patients' demographics, procedural complications (e.g., dissection and thromboembolism) and outcomes (estimated blood loss, transfusion requirements, immediate/delayed hysterectomy rate, postoperative sepsis, and immediate maternal/fetal mortality) were analysed. Results: Twenty-three cases were included in the study. The median age of the patients was 36 years (range, $28-47$ years). A total of $91.3 \%$ (21/23) were high-grade placenta praevia (34.8\% grade III and $56.5 \%$ grade IV) with $69.6 \%$ (16/23) co-existing placenta accreta. All prophylactic iliac balloon insertion procedures were uneventful without major complications such as dissection or thromboembolic events. The median blood loss was $1700 \mathrm{~mL}$ (100-8000 mL). The mean units of packed cells, platelets, and fresh frozen plasma transfused were 2.5, 2.2, and 2.0, respectively. The immediate and delayed hysterectomy rates were $34.8 \%(8 / 23)$ and $13.0 \%(3 / 23)$, respectively. Postoperative sepsis incidence was $8.7 \%$ (2/23). No immediate maternal or fetal mortality was recorded. Overall, the obstetric outcomes were comparable to data published in the literature.

Conclusion: Prophylactic Caesarean iliac artery balloon insertion for patients with abnormal placental implantation is feasible and safe. The obstetric outcomes were comparable to data published in the literature.
\end{abstract}

Key Words: Balloon occlusion; Iliac artery; Placenta accreta; Placenta previa; Radiology, interventional

\footnotetext{
Correspondence: Prof SCH Yu, Department of Imaging \& Interventional Radiology, Prince of Wales Hospital, Hong Kong Email:simonyu@cubk.edu.hk
}

Submitted: 6 Aug 2019; Accepted: 10 Dec 2019

Contributors: All authors designed the study. CSCT, SSMW and CMYC acquired the data. CSCT and SSMW analysed the data and drafted the manuscript. All authors critically revised the manuscript for important intellectual content. All authors had full access to the data, contributed to the study, approved the final version for publication, and take responsibility for its accuracy and integrity.

Conflicts of Interest: All authors have disclosed no conflicts of interest.

Funding/Support: This research received no specific grant from any funding agency in the public, commercial, or not-for-profit sectors.

Data Availability: All data generated or analysed during the present study are available from the corresponding author on reasonable request.

Ethics Approval: This study was approved by the Joint Chinese University of Hong Kong-New Territories East Cluster Clinical Research Ethics Committee (Ref 2019.577). The requirement for patient consent was waived for this retrospective study. 


\title{
中文摘要
}

\section{異常胎盤植入患者預防性剖宮產髂動脈球囊置入術}

\author{
蔡紹俊、王先民、鍾汶欣、余俊豪 \\ 引言：評估接受預防性剖宮產髂骨球囊置入術的異常胎盤植入患者的安全性和產科結果。 \\ 方法：回顧2009 年 9 月至 2016 年 4 月期間在三級轉介醫院接受預防性剖宮產髂動脈球囊置入術的異 \\ 常胎盤植入患者（即第三級或第四級前置胎盤以及/或者植入性胎盤）的臨床和手術記錄。分析患 \\ 者的基本資料訊息、手術併發症（如撕裂和血栓栓塞）和結果（估計失血量、輸血需求、即時 / 延 \\ 遲子宮切除率、術後敗血症和產婦 / 胎兒即時死亡率）。 \\ 結果 : 共納入 23 例。患者年齡中位數為36歲（介乎28-47歲）。23名患者中，21名（91.3\%）出現嚴 \\ 重前置胎盤（第三級佔 $34.8 \%$, 第四級佔 $56.5 \%$ ) ，16名（69.6\%）併有胎盤植入。所有預防性髂骨 \\ 球囊置入術均成功, 沒有出現撕裂或血栓栓塞事件等重大併發症。失血量中位數為1700 毫升（介乎 \\ 100-8000毫升）。紅血球濃厚液、血小板和新鮮冷凍血漿的平均用量分別為 2.5 、 2.2 和 2.0 。即時和延 \\ 遲子宮切除率分別為 $34.8 \%$ （8例）和13.0\%（3例）。術後敗血症發生率為 8.7\%（2例）。沒有錄得 \\ 產婦 / 胎兒即時死亡。總體而言, 產科結果與文獻數據相若。
}

結論 : 胎盤植入異常患者進行預防性剖宮產髂動脈球囊置入術是可行且安全的。產科結果與文獻數 據相若。

\section{INTRODUCTION}

Abnormal placental implantation represents a major challenge to obstetricians in terms of its high risks of massive haemorrhage, disseminated intravascular coagulopathy, sepsis, and the resulting maternal and/or fetal mortality. Risk factors for placenta accreta include placenta praevia, previous Caesarean section, uterine surgery, multiparity, and advanced maternal age. ${ }^{1}$ With a rising incidence of abnormal placental implantation in recent years due to increasing surgical delivery rates worldwide, ${ }^{2}$ multidisciplinary input from obstetricians, obstetric anaesthetists, and interventional radiologists are recognised as pivotal to improve obstetric outcomes.

An interventional radiology approach for management of patients with placenta accreta and its variants was first described by Dubois et al in 1997. ${ }^{3}$ It involved prophylactic balloon occlusion of the anterior division of the internal iliac arteries followed by uterine artery embolisation. Since then, investigations have been carried out by various groups looking into its clinical efficacy. In a retrospective study by Tan et $\mathrm{al},{ }^{4}$ preoperative internal iliac artery balloon occlusion reduced intraoperative blood loss and transfusion requirements in patients with placenta accreta and its variants undergoing Caesarean delivery. Other studies by Shrivastava et al ${ }^{5}$, Bodner et al, ${ }^{6}$ and Salim et $\mathrm{al}^{7}$ failed to show benefit of prophylactic balloon occlusion in terms of blood loss reduction or transfusion requirements. Therefore, its role in management of abnormal placental implantation remains controversial. Our study aimed to further evaluate the safety and obstetric outcomes of patients who received prophylactic Caesarean iliac artery balloon insertion.

\section{METHODS \\ Study Design and Patients}

This was a retrospective case series study, reported in accordance with the Strengthening the Reporting of Observational Studies in Epidemiology (STROBE) guidelines. ${ }^{8}$ The clinical records and procedural details of 23 consecutive patients with a high suspicion of abnormal placental implantation, based on clinical risk factors and ultrasonographic and magnetic resonance imaging findings, that underwent prophylactic Caesarean iliac artery balloon insertion in the period from September 2009 to April 2016 were retrospectively reviewed.

\section{Procedure}

The internal iliac balloon insertions were performed on an elective basis in the angiography suite of the radiology department. Balloon insertion procedures were performed by a senior interventional radiologist with 
18 years of experience (SCHY). Bilateral femoral punctures were performed and 7-Fr femoral sheaths (Radifocus; Terumo Corporation, Tokyo, Japan) introduced. Both internal iliac arteries were sequentially cannulated with 5-Fr catheters (RIM; Cook Medical, Bloomington [IN], US) over a guidewire (Terumo) using the contralateral approach (i.e., cannulation of the left internal iliac artery via right femoral access and vice versa). A 6-Fr compliance balloon catheter (Berenstein Occlusion Balloon, Boston Scientific, Natick [MA], US) was placed in the main trunk or anterior division of each internal iliac artery (Figure 1). The balloon catheters were connected to a container with 0.4 to $0.7 \mathrm{~mL}$ contrast (Omnipaque, GE Healthcare). The catheters were then carefully anchored to the inguinal region with sutures and semipermeable polyurethane membranes (Tegaderm, $3 \mathrm{M}$ Healthcare, St. Paul [MN], US) and taped to the lower limbs (Figure 2). In order to reduce procedural radiation dose, a low pulse rate ( $\leq 6.25$ frames/s), coning/shielding, and avoidance of digital subtraction angiography (with roadmap only) were adopted.

Patients were then transferred to the obstetric theatre for Caesarean delivery. Inflation of the balloon catheters

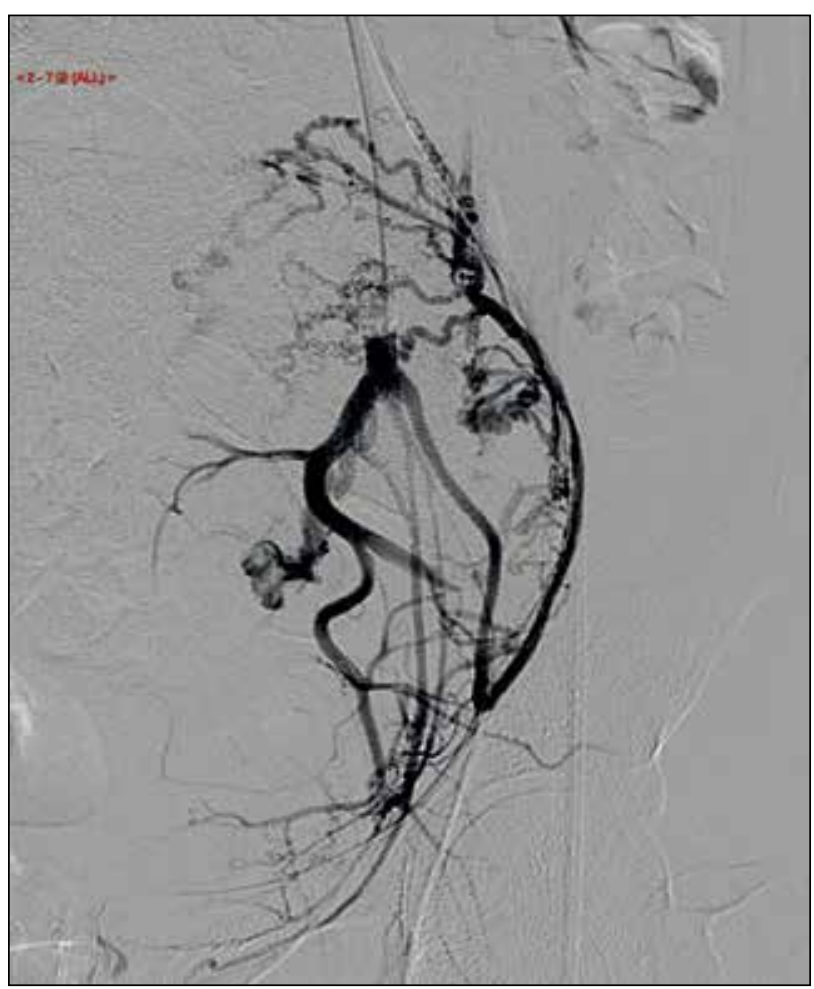

Figure 1. Digital subtraction angiographic image showing balloon in situ within the internal iliac artery.

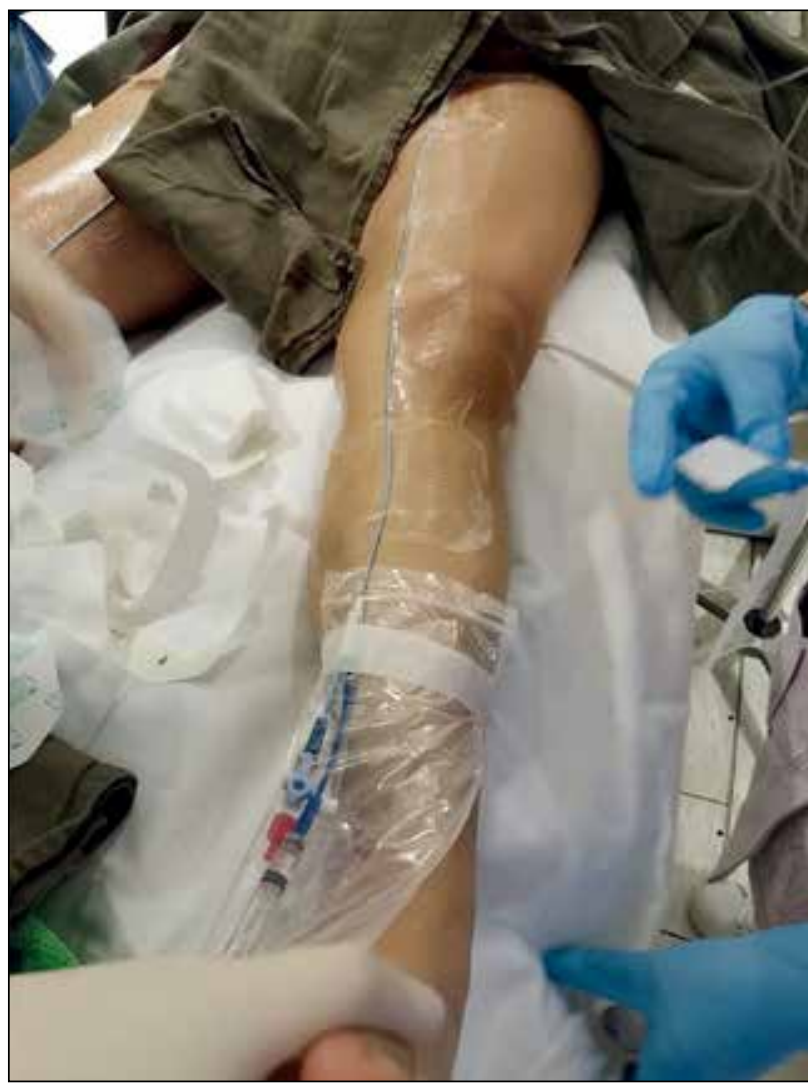

Figure 2. Balloon catheters carefully affixed to the inguinal regions and lower limbs with sutures and semipermeable polyurethane membranes.

was performed by the attending obstetricians after the fetus was fully delivered and the umbilical cord clamped. The need for balloon inflation would be assessed by the obstetrician depending on the degree of postpartum haemorrhage, which also determined subsequent management with options including primary hysterectomy, a conservative approach with uterus and placenta in situ or uterine artery embolisation (Figures 3 and 4) using an absorbable gelatine sponge slurry (Gelfoam; Upjohn, Kalamazoo [MI], US). The obstetricians had the option of checking the balloon catheters' position intraoperatively using a $\mathrm{C}$-arm if necessary. Intravenous antibiotics were not routinely administered unless there were signs of endometritis.

The diagnosis of placenta accreta was confirmed either intraoperatively when the placenta failed to be detached with gentle controlled cord traction or pathologically when the uterus and placenta were removed. For patients with the placenta left in situ, serial ultrasound was performed to monitor involution of the placenta in the postoperative period. 


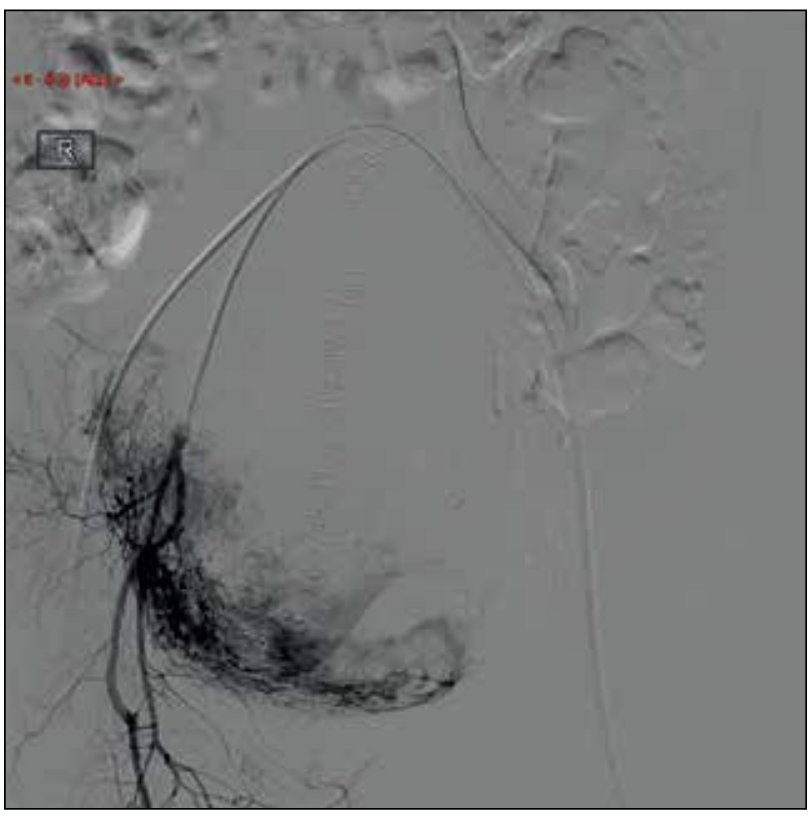

Figure 3. Digital subtraction angiographic image showing contrast blushing and extravasation suggestive of active bleeding from uterine artery.

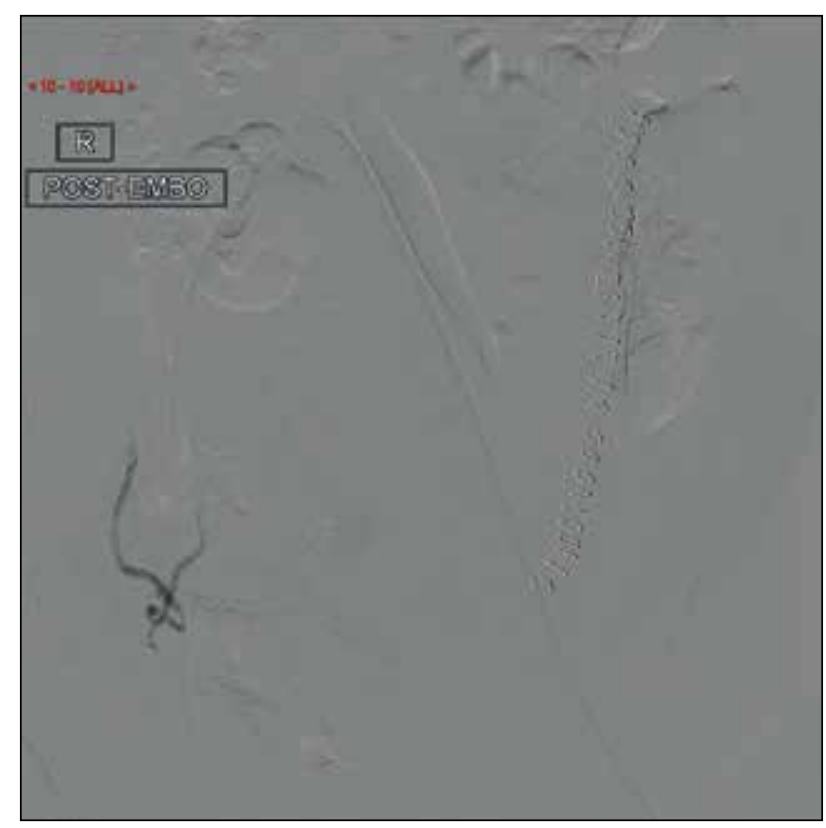

Figure 4. Digital subtraction angiographic image showing status after uterine artery embolisation artery embolisation.

\section{Statistical Analysis}

Basic patient demographics including the patients' age, gestational age, gravidity and parity, history of Caesarean section, and other uterine surgery were recorded. Obstetric outcomes, including estimated blood loss during Caesarean section (as documented in the surgical record), requirements for blood product transfusion (packed red blood cells [PRBCs], platelets, and fresh frozen plasma [FFP]), hysterectomy rate (including whether it was immediate or delayed), and complications related to hysterectomy and balloon insertion were also recorded.

Parametric variables are presented as mean and standard deviation while non-parametric variables are presented as median and range. Categorical variables are presented as percentages. Statistical analysis was performed using commercial software (SPSS Windows version 19.0; IBM Corp, Armonk [NY], US).

\section{RESULTS Patient Cohort}

From September 2009 to April 2016, 24 prophylactic iliac artery balloon insertions were performed. One case performed for uterine arteriovenous malformations was excluded, leaving a total of 23 cases for analysis. The basic demographics of our patients are described in Table 1. This group of patients demonstrated known risk factors for abnormal placental implantation, such as relatively advanced maternal age (median age $=36$ years) and a history of Caesarean section or uterine surgery/ curettage (74\% of current patient cohort). Median gravidity was 3 (range, 1-7) and parity was 1 (range, 0-3).

In these 23 cases, $69.6 \%(16 / 23)$ had the diagnosis of placenta accreta or its variants confirmed either intraoperatively or pathologically. A high percentage of the cases had co-existing high-grade placenta praevia of grade III $(34.8 \% ; 8 / 23)$ or IV $(56.5 \% ; 13 / 23)$ [Table 1$]$.

Among the 23 cases, bleeding in two cases was deemed not excessive and thus the obstetricians decided inflation of the balloon catheters was not necessary. One of these two cases had no accreta, as cord traction resulted in complete separation of the placenta from the uterine wall and the placenta was found to be complete. Inflation of the balloons was not clearly documented in another case, for a total percentage of confirmed actual balloon inflation of $87 \%(20 / 23)$.

\section{Obstetric Outcome}

The estimated median blood loss during Caesarean section was $1700 \mathrm{~mL}$ (range, 100-8000 mL). Blood product transfusions thus were required by most patients, with a mean of $2.5( \pm 3.7)$ units of PRBCs, $2.2( \pm 3.6)$ units of platelet, and $2.0( \pm 3.4)$ units of FFP. 
Table 1. Patient demographics $(n=23)$.

\begin{tabular}{lc}
\hline Demographics & \\
\hline Age, y & $36(28-47)$ \\
Gravidity & $3(1-7)$ \\
Parity & $1(0-3)$ \\
Gestational age, wk & $37(28-38)$ \\
Previous Caesarean section & $1(0-2)$ \\
Previous uterine surgery & $17(73.9 \%)$ \\
High-grade placenta praevia (grade III/IV) & $21(91.3 \%)$ \\
Placenta accreta and its variants & $16(69.6 \%)$ \\
\hline
\end{tabular}

* Data are shown as No. (\%) or median (range).

Table 2. Summary of obstetric outcomes. *

\begin{tabular}{lc}
\hline Estimated blood loss during Caesarean, $\mathrm{mL}$ & $1700(100-8000)$ \\
Packed red cell transfusions, unit & $2.5 \pm 3.7$ \\
Platelet transfusions, unit & $2.2 \pm 3.6$ \\
Fresh frozen plasma transfusions, unit & $2.0 \pm 3.4$ \\
Hysterectomy rate & $47.8 \%$ \\
& (immediate: $35 \% ;$ \\
Postoperative sepsis & delayed: $13 \%)$ \\
\hline
\end{tabular}

* Data are shown as median (range) or mean \pm standard deviation, unless otherwise specified.

Immediate hysterectomy, primarily in order to control blood loss, was performed in eight cases (35\%) while delayed hysterectomy was performed in three cases, due to endometritis, placental infection, and haemoperitoneum post-Caesarean section. Four cases had retained placenta due to morbid adhesion and did not require hysterectomy. Two of the four cases subsequently developed infection of the retained placenta and one required a delayed hysterectomy. No major structural complications were reported. One case of loss of bladder sensation was documented. There were no reported injuries to the ureters or bowel during hysterectomy or Caesarean section. Immediate postoperative uterine artery embolisation was carried out in five patients $(21.7 \%$; 5/23). Only one patient required repeated uterine artery embolisation, which was performed to control bleeding from a retained placenta 2 months after the delivery. Postoperative sepsis was documented in $8.7 \%(2 / 23)$ of patients (Table 2$)$.

\section{Technical Outcome}

All the iliac balloon insertions were technically successful. No balloon-related complications such as vascular dissection or thromboembolism were reported in these 23 cases. There was one case of balloon selfdeflation where reinflation was needed due to a loosened 3-way stopcock.
The mean radiation dose to the mother incurred in the prophylactic Caesarean catheter insertion was $177000 \pm 244251 \mathrm{mGycm}^{2}$, while mean fluoroscopic screening time was $373 \pm 228$ s. Estimated effective dose was $46 \mathrm{mSv}$ (conversion factor 0.26 , adopted from The National Council on Radiation Protection and Measurements 2009). ${ }^{9}$ Mean fetal dose was $11.2 \mathrm{mGy}$.

\section{DISCUSSION}

The basic demographics of our current cohort of patients with relatively advanced maternal age, and a high prevalence of previous Caesarean section/ uterine surgery, show similarity to data published in the literature. ${ }^{4-6}$ The high percentage of intraoperatively/ pathologically diagnosed placenta accreta or its variants and co-existing high praevia are consistent with the findings of Shrivastava et $\mathrm{al}^{5}$ and Salim et al. ${ }^{7}$

In the assessed obstetric outcomes, the estimated amount of blood loss was comparable to published data on patients undergoing balloon occlusion. The requirement for blood product transfusion (PRBCs, platelets, and FFP) varies significantly in the literature (Table $3^{4,5,7,10}$ ), with total units of blood product transfusion up to 10 in a balloon catheter intervention group. ${ }^{5}$ In contrast to this, estimated blood loss and the need for blood products was comparable/comparatively moderate in this cohort of patients.

Conflicting evidence is observed in the literature regarding the efficacy of the placement of internal iliac artery balloons. In 2012, Dilauro et $\mathrm{al}^{11}$ analysed 20 case reports, including three case-control studies, seven multiple-case series, and 10 single-case reports involving a total of 132 patients who underwent this procedure, and found that the reduction in postpartum haemorrhage or transfusion requirements were inconsistent among different investigators. Tan et $\mathrm{al}^{4}$ reported a significant decrease in intraoperative blood loss in patients with occlusion balloon versus Caesarean section alone $(2011 \mathrm{~mL}$ vs. $3316 \mathrm{~mL} ; \mathrm{p}=0.042)$ and reduction in required blood transfusion volume $(1058 \mathrm{~mL}$ vs. $2211 \mathrm{~mL} ; \mathrm{p}=0.005)$. Angstmann et $\mathrm{al}^{12}$ demonstrated a significant decrease in intraoperative blood loss (553 mL vs. $4517 \mathrm{~mL} ; \mathrm{p}<0.001)$ and the need for transfusion $(p=0.001)$. However, other studies such as Levine et al ${ }^{13}$ Shrivastava et al, ${ }^{5}$ and Salim et al ${ }^{7}$ showed no significant differences in estimated intraoperative blood loss, need for transfused blood products, or length of hospital stay. The available literature is mostly smallscale retrospective studies and very few randomised 
Table 3. Obstetric outcomes in other studies.

\begin{tabular}{|c|c|c|c|c|c|}
\hline & Sample size & $\begin{array}{l}\text { Estimated blood } \\
\text { loss }\end{array}$ & $\begin{array}{l}\text { Blood products } \\
\text { transfusion }\end{array}$ & $\begin{array}{l}\text { Complications } \\
\text { related to } \\
\text { hysterectomy }\end{array}$ & $\begin{array}{l}\text { Balloon insertion-related } \\
\text { complications }\end{array}$ \\
\hline Tan et $\mathrm{al}^{4}$ & $\begin{array}{l}25 \text { (11 in the study } \\
\text { group; } 14 \text { in the } \\
\text { control group) }\end{array}$ & $\begin{array}{l}2011 \mathrm{~mL} \\
(400-5000 \mathrm{~mL})^{\star}\end{array}$ & $\begin{array}{l}1058 \mathrm{~mL} \text { (mean volume } \\
\text { of RBCs transfused); } \\
\text { transfusion of other blood } \\
\text { products not recorded }\end{array}$ & Not recorded & Nil \\
\hline $\begin{array}{l}\text { Shrivastava } \\
\text { et al }\end{array}$ & $\begin{array}{l}69 \text { (19 patients in } \\
\text { balloon catheter } \\
\text { group; } 50 \text { patients in } \\
\text { the control group) }\end{array}$ & $\begin{array}{l}2700 \mathrm{~mL} \\
(800-8000 \mathrm{~mL})^{\dagger}\end{array}$ & $\begin{array}{l}10 \text { units (type and number } \\
\text { of individual blood } \\
\text { products not recorded) }\end{array}$ & Not recorded & $\begin{array}{l}\text { 15.8\% }(3 / 19) \text { patients had } \\
\text { severe catheter-related } \\
\text { complications: } \\
\text { - lliac artery thrombosis + } \\
\text { inguinal haematoma }(n=1) \\
\text { - Internal iliac artery } \\
\text { dissection }(n=1) \\
\text { - Femoral artery thrombosis } \\
(n=1)\end{array}$ \\
\hline Thon et $\mathrm{al}^{10}$ & 14 & $\begin{array}{l}4632 \\
(7000-15,000 \mathrm{~mL})^{\star}\end{array}$ & $\begin{array}{l}\text { RBC: } 4 \text { units }(0-21)^{\dagger} \\
\text { FFP: } 0 \text { units }(0-16)^{\dagger} \\
\text { Platelet: } 0 \text { units }(0-6)^{\dagger}\end{array}$ & Not recorded & $\begin{array}{l}\text { 14.3\% }(2 / 14) \text { had catheter- } \\
\text { related complications: } \\
\text { - Groin haematoma }(n=1) \\
\text { - Catheter migration }(n=1) \\
\text { - Transient leg ischaemia } \\
\text { ( } n=1 \text {; same patient with } \\
\text { catheter migration) }\end{array}$ \\
\hline Salim et $\mathrm{al}^{7}$ & $\begin{array}{l}27 \text { (13 patients in the } \\
\text { intervention group; } \\
14 \text { in the control } \\
\text { group) }\end{array}$ & $\begin{array}{l}1500 \mathrm{~mL} \\
(800-4000 \mathrm{~mL})^{\dagger}\end{array}$ & $\begin{array}{l}\text { RBC: } 3 \text { units }(0-23)^{\dagger} \\
\text { FFP: } 0 \text { units }(0-19)^{\dagger} \\
\text { Platelet: } 0 \text { units }(0-6)^{\dagger}\end{array}$ & $\begin{array}{l}15.4 \%(2 / 13) \text { with } \\
\text { bladder injury }\end{array}$ & $\begin{array}{l}15.4 \% \text { patients }(2 / 13) \text { had } \\
\text { balloon catheter related } \\
\text { complications: } \\
\text { - Transient right leg pain and } \\
\text { weakness }(n=1) \\
\text { - Transient buttock } \\
\text { claudication }(n=1)\end{array}$ \\
\hline
\end{tabular}

Abbreviations: FFP = fresh frozen plasma; $\mathrm{RBC}=$ red blood cell.

* Data are shown as mean (range).

+ Data are shown as median (range).

controlled studies. ${ }^{7}$ We believe that non-standardisation of procedure techniques, operator experience, and factors such as patient referral pattern and selection bias are causing such inconclusive evidence and thus the ambiguity about its efficacy. Also, there are potential ethical limitations in performing randomised controlled studies in this group of patients with high obstetric risks leading to only very few randomised prospective studies in this topic.

Reasons for failure to reduce intraoperative risks of bleeding or obstetric outcomes may be due to the presence of extensive vascular anastomoses in the gravid uterus. The collateral arterial supply from the cervical, ovarian, rectal, and even lumbar arteries can contribute to overall blood loss ${ }^{19}$ even the uterine arteries have been occluded by balloon catheters. Kidney et $\mathrm{al}^{14}$ have argued that the presence of distended balloons reduces arterial pressure to that of venous pressure, and by this means, haemostasis and blood clot formation can be facilitated.
Therefore, investigators have also been trying to modify the balloon occlusion technique by placing the balloon at more proximal sites, such as at the common iliac arteries or the infrarenal abdominal aorta. This was performed with an aim to arrest the extensive collateral flow arising proximal to the internal iliac arteries. Omar et al $^{15}$ reviewed 19 studies, including 57 cases of prophylactic arterial balloon occlusion performed at multiple sites, including the abdominal aorta, common iliac arteries, internal iliac arteries, the anterior division of the internal iliac arteries and the uterine arteries. The authors observed there is more conflicting evidence when balloons were placed in the internal iliac arteries or the uterine arteries, with one positive controlled study ${ }^{4}$ and three negative controlled studies. ${ }^{5,6,13}$ Angstmann et a ${ }^{12}$ placed balloon occlusion catheters in the common iliac arteries and yielded positive result with reduction in maternal morbidity. Authors of three case reports using balloon occlusion in the abdominal aorta reported favourable outcome as well. ${ }^{16-18} \mathrm{~A}$ more recent study 
performing temporary occlusion of the infrarenal aorta in 42 cases also gave favourable outcomes (estimated blood loss $0.58 \mathrm{~L}$ ). ${ }^{19}$ Omar et a ${ }^{15}$ postulated the clinical success could be proportional to the ability of abolishing the extensive collateral blood supply. To support or validate this deduction, large-scale randomised and prospective studies will be required. The safety profile of more proximal balloon occlusion, such as in the common iliac arteries or abdominal aorta, will have to be carefully evaluated because potential complications include lower limb ischaemia, lower limb embolism, reperfusion injury, vessel thrombosis, and aortic rupture. Also, aortic balloons have a much larger profile and are thus more prone to migration during inflation. Its inflation process will also likely increase the blood pressure due to significant obstruction to circulation.

In our review of the procedural records of these 23 prophylactic internal iliac balloon catheter insertions, it showed that this procedure could be performed safely and was feasible. No major significant balloon insertion-related complications were found in this cohort of patients. However, arterial thrombosis, a major complication requiring thrombectomy, ${ }^{20,21}$ and minor complications such as transient leg pain, weakness, and claudication have been reported. ${ }^{7,10}$ This aspect is particularly important as major vascular complications could have significant implications in these patients. A well-defined safety profile will be essential in establishing the efficacy of this prophylactic procedure, assuming it is proven in randomised controlled trials to be of benefit.

There were no hysterectomy-related complications in terms of structural damage to the adjacent organs such as the bowel, ureters or urinary bladder. One case of loss of urinary bladder sensation was documented, however, which may have been caused by inadvertent damage to adjacent pelvic nerves.

It is always important to minimise radiation exposure to both mothers and especially fetuses, so meticulous techniques were employed, including low pulse rate ( $\leq 6.25 \mathrm{frame} / \mathrm{s}$ ), coning/shielding, and avoidance of digital subtraction angiography (with roadmap only). The mean fetal dose observed in the present study was $11.2 \mathrm{mGy}$. This represents a probability of birth without malformation or childhood cancer of approximately 95.8\% compared with $95.9 \%$ in children without radiation exposure. This probability is $0.1 \%$ higher than that in children born without radiation exposure during pregnancy. ${ }^{22}$ This needs to be balanced against the potential benefits of reduction of intraoperative blood loss and need for transfusion, ${ }^{4,12}$ again necessitating a randomised controlled multicentre trial.

The strength of current study was the consistency of the balloon catheter procedures, as it was carried out/supervised by single experienced interventional radiologist, and the relatively large number of patients. However, it is limited by its lack of a control group for direct comparison and the fact that not all patients were confirmed to have placenta accreta. Future studies with standardised procedure protocol in prospective setting will be helpful to evaluate and establish the clinical efficacy of prophylactic internal iliac balloon insertion.

In conclusion, we have demonstrated prophylactic internal iliac balloon insertion for patients with suspected abnormal placental implantation is safe and feasible. The obstetric outcomes were comparable to data in the major literature.

\section{REFERENCES}

1. Miller DA, Chollet JA, Goodwin TM. Clinical risk factors for placenta previa-placenta accreta. Am J Obstet Gynecol. 1997;177:210-4.

2. Matthews TG, Crowley P, Chong A, McKenna P, McGarvey C, O'Regan M. Rising caesarean section rates: a cause for concern? BJOG. 2003;1 10:346-9.

3. Dubois J, Garel L, Grignon A, Lemay M, Leduc L. Placenta percreta: balloon occlusion and embolization of the internal iliac arteries to reduce intraoperative blood losses. Am J Obstet Gynecol. 1997;176:723-6.

4. Tan CH, Tay KH, Sheah K, Kwek K, Wong K, Tan HK, et al. Perioperative endovascular internal iliac artery occlusion balloon placement in management of placenta accreta. AJR Am J Roentgenol. 2007;189:1158-63.

5. Shrivastava V, Nageotte M, Major C, Haydon M, Wing D. Casecontrol comparison of cesarean hysterectomy with and without prophylactic placement of intravascular balloon catheters for placenta accreta. Am J Obstet Gynecol. 2007;197:402.e1-5.

6. Bodner LJ, Nosher JL, Gribbin C, Siegel RL, Beale S, Scorza W. Balloon-assisted occlusion of the internal iliac arteries in patients with placenta accreta/percreta. Cardiovasc Intervent Radiol. 2006;29:354-61.

7. Salim R, Chulski A, Romano S, Garmi G, Rudin M, Shalev E. Precesarean prophylactic balloon catheters for suspected placenta accreta: a randomized controlled trial. Obstet Gynecol. 2015;126:1022-8.

8. von Elm E, Altman DG, Egger M, Pocock SJ, Gøtzsche PC, Vandenbroucke JP, et al. The Strengthening the Reporting of Observational Studies in Epidemiology (STROBE) statement: guidelines for reporting observational studies. Epidemiology. 2007;18:800-4.

9. National Council on Radiation Protection and Measurements. Report 160 - Ionizing Radiation Exposure of the Population of the United States. Available from: https://ncrponline.org/publications/ reports/ncrp-report-160-2/. Accessed 11 Jun 2019. 
10. Thon S, McLintic A, Wagner Y. Prophylactic endovascular placement of internal iliac occlusion balloon catheters in parturients with placenta accreta: a retrospective case series. Int $\mathrm{J}$ Obstet Anesth. 2011;20:64-70.

11. Dilauro MD, Dason S, Athreya S. Prophylactic balloon occlusion of internal iliac arteries in women with placenta accreta: literature review and analysis. Clin Radiol. 2012;67:515-20.

12. Angstmann T, Gard G, Harrington T, Ward E, Thomson A, Giles W. Surgical management of placenta accreta: a cohort series and suggested approach. Am J Obstet Gynecol. 2010;202:38.e1-9.

13. Levine AB, Kuhlman K, Bonn J. Placenta accreta: comparison of cases managed with and without pelvic artery balloon catheters. J Matern Fetal Med. 1999;8:173-6.

14. Kidney DD, Nguyen AM, Ahdoot D, Bickmore D, Deutsch LS, Majors C. Prophylactic perioperative hypogastric artery balloon occlusion in abnormal placentation. AJR Am J Roentgenol. 2001;176:1521-4

15. Omar HR, Karlnoski R, Mangar D, Mangar D, Patel R, Hoffman M, Camporesi E. Staged endovascular balloon occlusion versus conventional approach for patients with abnormal placentation: a literature review. J Gynecol Surg. 2012;28:247-54.

16. Paull JD, Smith J, William L, Davison G, Devine T, Holt M. Balloon occlusion of the abdominal aorta during caesarean hysterectomy for placenta percreta. Anaesth Intensive Care. 1995;23:731-4

17. Bell-Thomas SM, Penketh RJ, Lord RH, Davies NJ, Collis R. Emergency use of a transfemoral aortic occlusion catheter to control massive haemorrhage at caesarean hysterectomy. BJOG. 2003;110:1120-2.

18. Masamoto H, Uehara H, Gibo M, Okubo E, Sakumoto K, Aoki Y Elective use of aortic balloon occlusion in caesarean hysterectomy for placenta previa percreta. Gynecol Obstet Invest. 2009;67:92-5.

19. Duan XH, Wang YL, Han HW, Chen ZM, Chu QI, Wang L, et al. Caesarean section combined with temporary aortic balloon occlusion followed by uterine artery embolisation for the management of placenta accreta. Clin Radiol. 2015;70:932-7.

20. Sewell MF, Rosenblum D, Ehrenberg H. Arterial embolus during common iliac balloon catheterization at cesarean hysterectomy. Obstet Gynecol. 2006;108:746-8.

21. Royal College of Obstetricians \& Gynaecologists. Placenta praevia, placenta praevia accreta and vasa praevia: diagnosis and management (Green-top Guideline No. 27). 2011. Available from: https://www.rcog.org.uk/en/guidelines-research-services/ guidelines/gtg27/. Accessed 17 Jun 2019.

22. McCollough CH, Schueler BA, Atwell TD, Braun NN, Regner DM, Brown DL, et al. Radiation exposure and pregnancy: when should we be concerned? Radiographics. 2007;27:909-17. 